\title{
Study of the composition of mango pulp and whey for lactic fermented beverages
}

\author{
Rafael Resende Maldonado ${ }^{\mathrm{a}^{* * *}} \oplus$, Roberto Elias Buosi ${ }^{\mathrm{b}}$, Octávio Avancini Neto ${ }^{\mathrm{b}} \odot$,

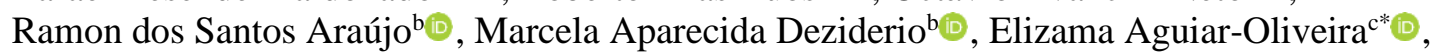 \\ Rodrigo Rodrigues Petrus ${ }^{\mathrm{d}} \odot$, Eliana Setsuko Kamimura ${ }^{\mathrm{d}} \odot$
}

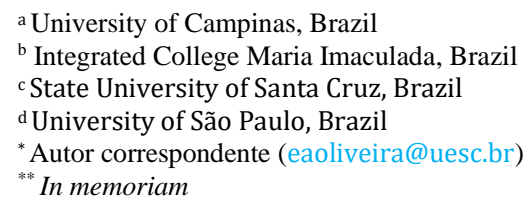

\section{N F O}

\section{Keyworks}

fermentation

fruit pulp

lactic acid bacteria

Mangifera indica

mixture design

\begin{abstract}
A B S T R A C T
Fermented lactic beverages have high sensory acceptance and may present probiotic microorganisms that are able to promote well-being. Milk is the primary substrate for this type of fermentation. However, more and more, consumers have been requesting for alternative formulations with lower (or absent) milk content. Two nutritional components can allow the reduction of milk in formulations: cheese whey $(\mathrm{CW})$ and fruit pulps. This study aimed to investigate, with the aid of the experimental design tool and sensory analysis, the best formulations between mango pulp (MP), CW and whole milk (WM) to develop lactic beverages fermented by Lactobacillus acidophilus $\mathrm{La}-5$ at $37^{\circ} \mathrm{C}$ for up to 72 $\mathrm{h}$. The results indicated that the increase in MP proportion associated with a decrease in WM elevated the sensory acceptance. Three formulations, with $24 \mathrm{~h}$ of fermentation, containing $55-100 \%(\mathrm{w} / \mathrm{w})$ of $\mathrm{MP}$ and $0-45 \%(\mathrm{w} / \mathrm{w})$ of $\mathrm{CW}$ were the best formulations and presented $\mathrm{pH}$ of $3.5-4.0$, cell count $>10^{8} \mathrm{CFU} / \mathrm{mL}$ and $82-88 \%$ of global acceptance. These results suggest MP or MP with $\mathrm{CH}$ as substrates for lactic fermentation replacing milk.
\end{abstract}

\section{R E S U M O}

Estudo da composição de polpa de manga e soro de queijo para bebidas láticas fermentadas. As bebidas láticas fermentadas apresentam alta aceitação sensorial e podem conter microrganismos probióticos que são capazes de promover o bem-estar. O leite é a principal matéria-prima para esse tipo de fermentação. No entanto, cada vez mais, os consumidores vêm solicitando formulações alternativas com menor composição (ou ausência) de leite. Dois componentes nutritivos podem permitir a redução do leite nas formulações: o soro de queijo (SQ) e polpas de fruta. Assim, este trabalho teve como objetivo investigar, com o auxílio da ferramenta de planejamento experimental e análise sensorial, as melhores formulações entre polpa de manga (PM), SQ e leite integral (LI) para o desenvolvimento de bebidas lácticas fermentadas por Lactobacillus acidophilus La-5 a $37^{\circ} \mathrm{C}$ por até $72 \mathrm{~h}$. Os resultados indicaram que o aumento da proporção de PM associado a diminuição de LI elevou a aceitação sensorial. Três formulações, com $24 \mathrm{~h}$ de fermentação, contendo $55-100 \%(\mathrm{p} / \mathrm{p})$ de PM e $0-45 \%(\mathrm{p} / \mathrm{p})$ de SQ foram as melhores formulações e apresentaram $\mathrm{pH}$ de 3,5 - 4,0, contagem de células $>10^{8} \mathrm{UFC} / \mathrm{mL}$ e $82-88 \%$ de aceitação global. Esses resultados sugerem PM ou PM com SQ como substratos para a fermentação láctica em substituição ao LI. 


\section{INTRODUCTION}

Lactic acid bacteria (LAB) are industrially important microorganisms and are used in industrial food fermentations, such as: yougurt (Huang et al., 2020), fermented milk (Abdel-Hamid et al., 2019), soy (Peirotén et al., 2020) and fruits (Isas et al., 2020). LAB are usually found in milk and dairy products, in plants and in the human and animal intestinal mucosa (Yerlikaya et al., 2020); they are capable of metabolizing different substrates and to improve nutritional properties (Garcia et al., 2020a). In addition, they are able to modify the profile of bioactive compounds and some physical-chemical and sensory characteristics besides to reduce lactose content and extend the shelf life by increasing acidity or producing bacteriocins (Daba and Elkhateeb, 2020; Wu et al., 2021). This group of bacteria has gained prominence due to the great potential to be used as probiotics (Peng et al., 2020). Among the various groups of bacteria classified as LAB, the most studied are Lactobacillus bulgaricus, Streptococcus thermophilus and Bifidobacteria spp. that are used industrially to produce yogurt (Yerlikaya et al., 2020).

The main raw material for lactic fermentation is milk (Peng et al., 2020), however, whey has been increasingly studied and applied for different fermented beverages (Guimarães et al., 2019). Whey is one of the main by-products of the cheese industry and is a source of vitamins, minerals and proteins such as sulphuramino acids which are particularly valuable due to their anticarcinogenic activities (Moussa and El-Gendy, 2019). Whey can contain approximately half the total amount of milk solids (e.g. proteins, lactose and mineral) and is estimated to be equivalent to $90 \%$ of milk volume. However, if disposed of incorrectly, it can be an environmental threat due to its high organic loads (Rama et al., 2019).

Another rich substrate for $\mathrm{LAB}$ fermentation can be suggested as different tropical fruit pulps (or juices) such as: Spondias dulcis (Souza et al., 2020a), Theobroma grandiflorum (Pereira et al., 2017), Syzygium cumini (Garcia et al., 2020b), Anacardium occidentale (Souza et al., 2020b) and many others. Fruit pulps can be potential substrates due to the incorporation of specific aromas (which improves sensory acceptance) and some specific nutrients. Furthermore, the fruit based fermented products are lactose free, which meet the needs of consumers with lactose intolerance, for example (Maldonado et al., 2017). Mango (Mangifera indica) is one of the tropical fruits with unique flavor and high nutritional value; some works were performed previously with mango and whey, for example: Andrade et al. (2019), Skyplonek et al.
(2019), Pandey and Ojha (2020) and Pandey et al. (2019). This study targeted the production of lactic fermented beverages based on mango, milk and whey. The fermentation conditions, and the physical-chemical, sensory and microbiological characteristics of the finished products were also investigated.

\section{MATERIAL AND METHODS}

\section{Preparation of mango pulp, milk and whey}

The mangoes utilized (Magnifica indica v. Tommy Atkins) were purchased locally (Mogi Guaçu, São Paulo, Brazil). The fruits were cleaned, peeled, and processed in a blender for the pulp preparation at the proportion 1:1 (mango pulp mass / distilled water mass). The pulp was pasteurized in batches $\left(80{ }^{\circ} \mathrm{C} / 5 \mathrm{~min}\right)$, hot filled in glass flasks, cooled to ambient temperature $\left(\sim 25^{\circ} \mathrm{C}\right)$ and then frozen at $-18^{\circ} \mathrm{C}$ (Maldonado et al., 2017; Nagpal et al., 2012).

Whey was obtained from the coagulation of whole fresh (unpasteurized) milk also supplied by a local producer. The coagulation process was realized with the addition of a lactic culture $\left(10^{6}\right.$ UFC/mL, Rhodia Foods ${ }^{\circledR}$ ) and rennet (Estrella ${ }^{\circledR}$ ). After one hour of coagulation, the whey was separated by filtration, pasteurized, and stored under the same conditions as the mango pulp. The whole milk was pasteurized and stored under the same conditions as the mango pulp and whey (Maldonado et al., 2017).

\section{Lactic fermentation}

The formulation of mango, milk, and wheybased lactic fermented beverages was evaluated using a Simplex Mixture Design for three components with ten different formulations (trials) (Bourscheid et al., 2014; Barros Neto et al., 2010). The minimum quantities of mango pulp and whey were defined at $40 \%$ and $30 \%(\mathrm{w} / \mathrm{w})$, respectively, based on a previous study (Maldonado et al., 2017). The statistical analysis was performed with STATISTICA v.8 (Statsoft).

The fermentations were conducted in sterilized flasks of $250 \mathrm{~mL}$, into which $150 \mathrm{~mL}$ of the substrates were added. A lyophilized lactic culture (LAB) containing Lactobacillus acidophilus La-5 $\left(10^{6} \mathrm{UFC} / \mathrm{mL}\right)$ was inoculated into each flask. The flasks were still kept at $37^{\circ} \mathrm{C}$ without agitation for $72 \mathrm{~h}$. Samples were collected every $24 \mathrm{~h}$ for assessing the titratable acidity, concentration of soluble solids (SS), and $\mathrm{pH}$. All formulations from the mixture design with $24 \mathrm{~h}$ of fermentation were selected for $\mathrm{LAB}$ cells counting (dilution $10^{-8}$ ) and sensorial analysis.

Two formulations were then selected from the 
data analysis: trial 1 [70\% (w/w) of mango and 30 $\%(\mathrm{w} / \mathrm{w})$ of whey] and trial 4 [55\% (w/w) of mango and $45 \%(\mathrm{w} / \mathrm{w})$ of whey). A sample containing 100 $\%(\mathrm{w} / \mathrm{w})$ of mango was also taken. They were all fermented (5 replicates) for $24 \mathrm{~h}$ and were sensory evaluated.

\section{Analytical methods}

Physico-chemical analysis: The physicochemical tests were carried out according to the standards described by the Instituto Adolfo Lutzs (IAL, 2005). For the determination of acidity titration was performed with a $\mathrm{NaOH} 0.1 \mathrm{~mol} / \mathrm{L}$ and phenolphthalein; the soluble solids content (SS, ${ }^{\circ}$ Brix) was measured with a portable refractometer (Instrumentep, São Paulo, Brazil) and the $\mathrm{pH}$ with a digital pHmeter (Digimed, São Paulo, Brazil).

Microbiological analysis: The LAB cell counting was performed by the colony forming units (CFU) method with serial decimal dilution of samples and plating (triplicate) in MRS (Man, Rogosa and Sharpe, Kasvi ${ }^{\circledR}$, Brazil) agar with incubation at $37{ }^{\circ} \mathrm{C} / 48 \mathrm{~h}$ (Fujita et al., 2017; Maldonado et al., 2017). Values were expressed per volume of fermented beverages $(\mathrm{CFU} / \mathrm{mL})$.

Sensory analysis: Based on previous work (Nogueira et al., 2016; Santos et al., 2008) and with approval of the Ethics Committee (CAAE n. 56661716.8.0000.5679), the sensory evaluation of the fermented beverages was conducted with untrained assessors. The attributes taste, aroma, color and overall acceptance were evaluated using a five-point just-about-right (JAR) scale $(5=$ liked very much and $1=$ disliked very much). Sweetness and acidity were assessed with a five-point ideality scale $(5=$ much higher than the ideal and $1=$ much lower than the model). The samples were produced accordingly to the good manufacturing practices and stored for one day in a fridge; prior to analysis, the samples were sweetened with $10 \%(\mathrm{w} / \mathrm{v})$ of sucrose to balance the acid/sweet ratio. For the first stage of analysis, ten selected formulations were evaluated by 15 untrained assessors and, for the second stage, three selected formulations were assessed by 58 untrained assessors. The results were evaluated by ANOVA and Tukey test, with a confidence level of $95 \%(p<0.05)$.

\section{RESULTS AND DISCUSSION}

\section{Lactic Fermentation}

The mango pulp, whey and milk-based lactic beverages were prepared according to the proportions defined by the matrix design shown in Table 1 . The obtained profiles for: $\mathrm{pH}$, acidity (\%, $\mathrm{v} / \mathrm{v}$ ) and soluble solids (SS, ${ }^{\circ} \mathrm{Brix}$ ) throughout the $72 \mathrm{~h}$ of fermentation (Fig. 1) demonstrate that the fermentation process, in the first $24 \mathrm{~h}$, resulted in abrupt decreases for $\mathrm{pH}$ and SS values but for the titratable acidity it was observed a continuous increase until the end of the $72 \mathrm{~h}$ of fermentation. The lactic acid, the main acid produced by LAB, is a weak acid and its increase in time, does not necessarily reflect a significant decrease of $\mathrm{pH}$, since it can may generate a buffering effect which tends to minimize the $\mathrm{pH}$ variations (Maldonado et al., 2017).

Table 1 - Coded Simplex Matrix with pseudo-components to evaluate the formulation of lactic fermented beverages with mango pulp, whey and milk. The responses presented are: cell count for lactic acid bacteria (LAB, $\log \mathrm{CFU} / \mathrm{mL}$ ) and the average score for some sensorial attributes ( $n=15$ assessors). The real proportions $(\%, \mathrm{w} / \mathrm{w})$ of the variables are exhibited in parentheses

\begin{tabular}{|c|c|c|c|c|c|c|c|c|c|c|}
\hline \multirow[b]{2}{*}{ Trial } & \multicolumn{3}{|c|}{ Variables } & \multicolumn{7}{|c|}{$\begin{array}{c}\text { Responses } \\
(24 \mathrm{~h})\end{array}$} \\
\hline & $\begin{array}{c}\text { Mango } \\
(\% \text { w/w })\end{array}$ & $\begin{array}{c}\text { Whey } \\
(\% \text { w/w) }\end{array}$ & $\begin{array}{c}\text { Milk } \\
(\% \mathrm{w} / \mathrm{w})\end{array}$ & $\begin{array}{c}\text { LAB } \\
(\log \text { CFU/mL) }\end{array}$ & Taste & Aroma & Color & $\begin{array}{l}\text { Overall } \\
\text { Accep- } \\
\text { tance }\end{array}$ & $\begin{array}{l}\text { Sweet- } \\
\text { ness }\end{array}$ & Acidity \\
\hline 1 & $1(701)$ & $0(30)$ & $0(0)$ & 6.4 & $4.2 \pm 0.5$ & $2.9 \pm 1.3$ & $4.6 \pm 0.5$ & $4.2 \pm 0.5$ & $3.2 \pm 0.4$ & $2.9 \pm 0.2$ \\
\hline 2 & $0(40)$ & $1(60)$ & $0(0)$ & 8.0 & $3.2 \pm 0.9$ & $2.9 \pm 1.2$ & $4.1 \pm 0.8$ & $3.2 \pm 0.9$ & $2.5 \pm 0.7$ & $2.8 \pm 0.8$ \\
\hline 3 & $0(40)$ & $0(30)$ & $1(30)$ & 14.6 & $2.7 \pm 1.0$ & $3.1 \pm 1.1$ & $3.2 \pm 1.2$ & $2.4 \pm 1.0$ & $2.1 \pm 0.7$ & $2.9 \pm 1.1$ \\
\hline 4 & $1 / 2(55)$ & $1 / 2(45)$ & $0(0)$ & $>100$ est. & $4.4 \pm 0.5$ & $3.1 \pm 1.1$ & $4.5 \pm 0.5$ & $4.3 \pm 0.6$ & $3.1 \pm 0.6$ & $3.1 \pm 0.4$ \\
\hline 5 & $1 / 2(55)$ & $0(30)$ & $1 / 2(15)$ & 13.4 & $2.9 \pm 0.9$ & $3.8 \pm 1.1$ & $3.7 \pm 0.9$ & $3.3 \pm 0.9$ & $2.6 \pm 0.6$ & $3.0 \pm 0.8$ \\
\hline 6 & $0(40)$ & $1 / 2(45)$ & $1 / 2(15)$ & $>100$ est. & $2.9 \pm 1.0$ & $3.6 \pm 1.0$ & $2.8 \pm 1.2$ & $3.1 \pm 1.2$ & $2.8 \pm 0.6$ & $3.4 \pm 0.5$ \\
\hline 7 & $1 / 3(50)$ & $1 / 3(40)$ & $1 / 3(10)$ & 11.3 & $3.7 \pm 0.7$ & $3.1 \pm 1.4$ & $3.8 \pm 0.8$ & $3.7 \pm 0.9$ & $3.1 \pm 0.4$ & $3.1 \pm 0.2$ \\
\hline 8 & $2 / 3(60)$ & $1 / 6(35)$ & $1 / 6(5.0)$ & $>100$ est. & $4.1 \pm 0.4$ & $3.9 \pm 0.8$ & $4.3 \pm 0.5$ & $3.7 \pm 0.5$ & $2.9 \pm 0.6$ & $3.1 \pm 0.5$ \\
\hline 9 & $1 / 6(45)$ & $2 / 3(50)$ & $1 / 6(5.0)$ & $>100$ est. & $2.9 \pm 0.7$ & $3.0 \pm 1.1$ & $3.3 \pm 0.8$ & $3.0 \pm 0.8$ & $2.8 \pm 0.8$ & $2.8 \pm 0.7$ \\
\hline 10 & $1 / 6(45)$ & $1 / 6(35)$ & $2 / 3(20)$ & 2.8 & $3.6 \pm 0.7$ & $3.3 \pm 0.8$ & $3.3 \pm 0.9$ & $3.3 \pm 0.7$ & $3.1 \pm 0.7$ & $2.7 \pm 0.6$ \\
\hline
\end{tabular}




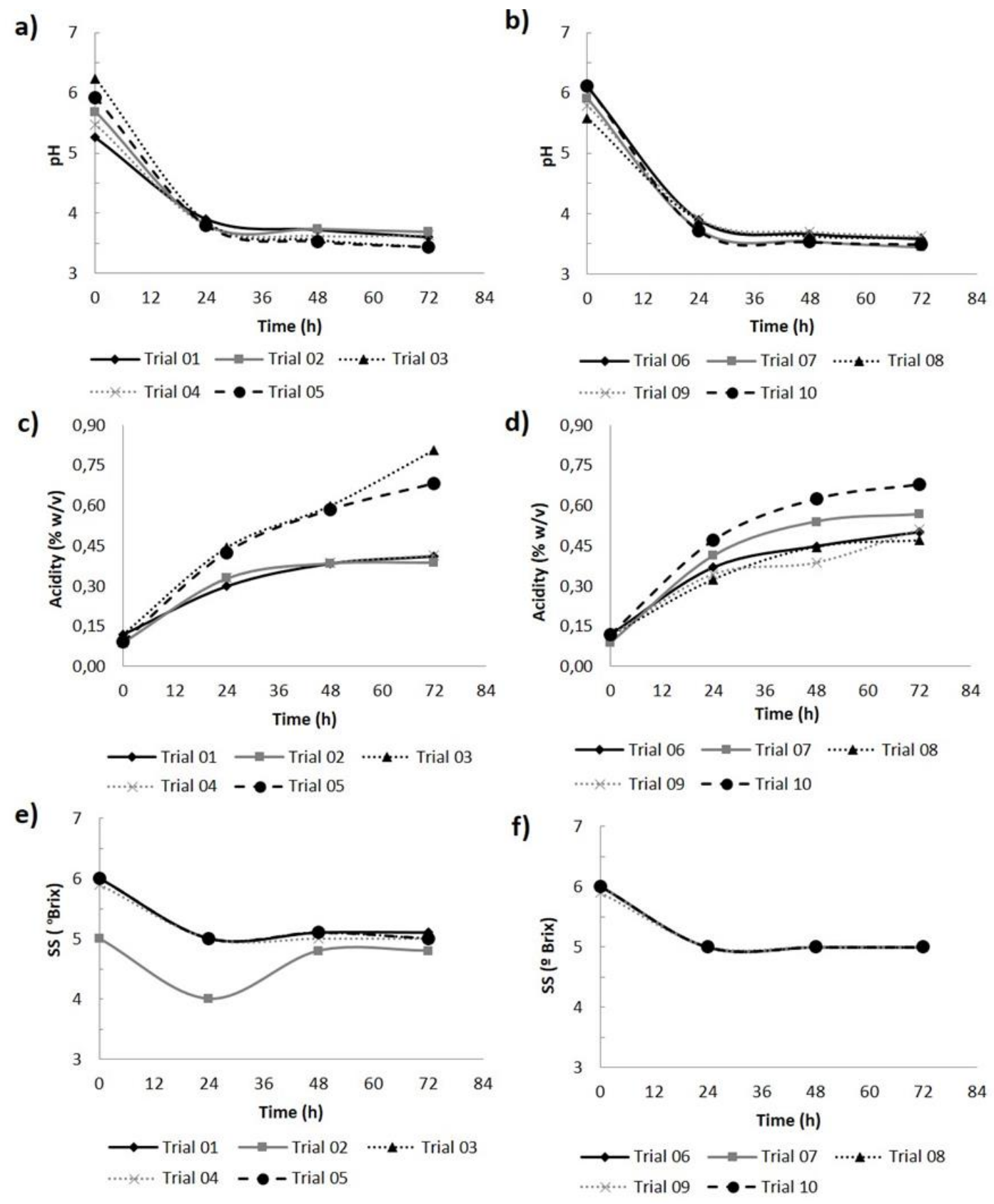

Figure 1 - Kinetic of fermentation for ten trials (formulations can be obtained at Table 1) of lactic fermented beverage using mango pulp, whey and whole milk during fermentation time for: a) and b) $\mathrm{pH}, \mathrm{c}$ ) and d) acidity $(\% \mathrm{w} / \mathrm{v}), \mathrm{e})$ and $\mathrm{f})$ soluble solids (SS $\left.{ }^{\circ} \mathrm{Brix}\right)$

The evaluation of the initial conditions is essential for formulation of beverages since the natural acidity of fruits may interfere in LAB's growth and survival (Fonteles et al., 2013; Di Cagno et al., 2011). For the initial $\mathrm{pH}$ values $(t=0$ h) it was possible to observe a statistical significant difference between values and it was possible to adjusted a codified model $\left(R^{2}=0.94 ; p<0.01\right)$ presented in Equation 1, which permitted to obtain its correspondent contour curve (Fig. 2.a). The results showed, as expected, that the increase in milk volume led to an increase in $\mathrm{pH}$ values, whereas the higher mango pulp proportion led to lower $\mathrm{pH}$ values. Despite the initial $\mathrm{pH}$ differences, after $24 \mathrm{~h}$, all the formulations presented similar $\mathrm{pH}$ values (Fig. 1.a and 1.b) with an average at $24 \mathrm{~h}$ of $3.84 \pm 0.07$ and it was not possible to identify a statistical significant difference $(p>0.05)$ between the formulations. Similar result was observed in previous studies also with mango pulp as substrate: pH 3.5 after $24 \mathrm{~h}$ (Maldonado et al., 2017) and pH $=3.2$ after $72 \mathrm{~h}$ (Reddy et al., 2015).

$$
\begin{aligned}
& p H(t=0 h)=(5.33) \cdot(\text { Mango })+(5.74) \cdot \\
& (\text { Whey })+(6.38) \cdot(\text { Milk })
\end{aligned}
$$


a) $\mathrm{pH}(t=0 \mathrm{~h})$

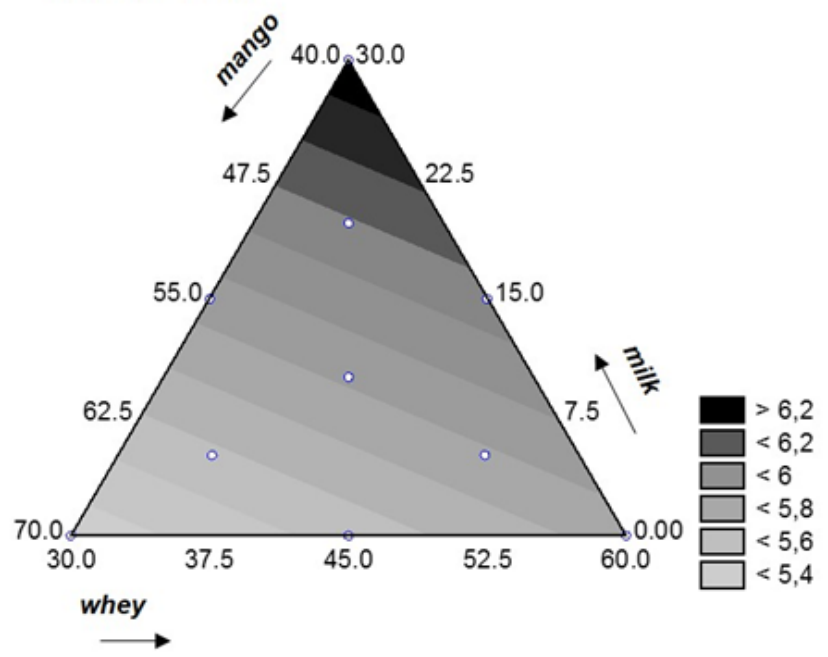

b) Acidity $(t=24 \mathrm{~h})$

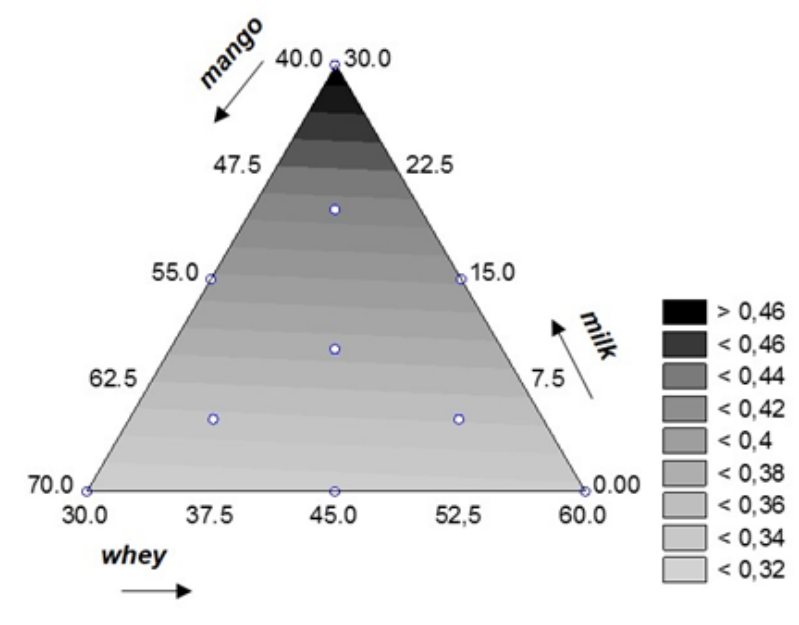

Figure 2 - Contour curves for a) the initial $\mathrm{pH}(t=0 \mathrm{~h})$ and b) the final acidity $(t=24 \mathrm{~h})$ of lactic fermented beverages developed with different proportions $(\%, w / w)$ of mango pulp, whey and whole milk.

In comparison to $\mathrm{pH}$, the titratable acidity presented an opposite behaviour since there was no statistically significant difference $(p>0.05)$ between formulations at $t=0$ (as it can be observed at Figures 1.c and 1.d), however, there was a statistically significant difference $(p<0.05)$ after $24 \mathrm{~h}$. The acidity values varied from an average value of $0.11 \pm 0.01 \%(\mathrm{w} / \mathrm{w})($ at $t=0 \mathrm{~h})$ to values between 0.30 to $0.47 \%$ (w/w) (after $24 \mathrm{~h})$, due to the metabolism of $\mathrm{LAB}$ in different formulations. The acidity data $(24 \mathrm{~h})$ was adjusted to a coded model $\left(R^{2}=0.75 ; p<0.05\right)$ presented in Equation 02 and the obtained contour curve can be observed in Figure 2.b. From the results (Fig. 2.b) it was possible to observe that, similarly for what was observed for the higher $\mathrm{pH}$ values (Fig. 2.a), the formulations with higher mango and lower milk proportions resulted in higher titratable acidities, for example, formulations (trials) 10 and 3 (compositions at Tab. 1) resulted in the highest acidities [0.47 and $0.44 \%$ (w/w), respectively]. LAB can ferment different substrates, but milk is their natural habitat and fermentation tend to be faster which could explain higher titratable acidities. In a previous work from the research group (Maldonado et al., 2017), it was obtained a $0.5 \%(\mathrm{v} / \mathrm{v})$ of titratable acidity for LAB fermentation $(24 \mathrm{~h})$ with only mango as a substrate and a smaller value $(0.3 \%$ v/v $)$ with equal proportions of mango and whey.

$$
\begin{aligned}
& \text { Acidity }(t=24 h)=(0.32) \cdot(\text { Mango })+ \\
& (0.33) \cdot(\text { Whey })+(0.48) \cdot(\text { Milk })
\end{aligned}
$$

Considering the soluble solids content (SS,
${ }^{\circ}$ Brix) it was not possible to confirm a statistical significant difference $(p>0.05)$ between all formulations, since they resulted in similar SS values at both: $t=0 \mathrm{~h}\left(5.8 \pm 0.3^{\circ} \mathrm{Brix}\right)$ and $t=24 \mathrm{~h}$ $\left(4.9 \pm 0.3^{\circ}\right.$ Brix $)$, as it can be observed at Figures 1.e and 1.f. Reddy et al. (2015) also observed a reduction in SS with a probiotic mango lactic fermented beverages from 12.0 to $5.8{ }^{\circ}$ Brix, after $72 \mathrm{~h}$ of fermentation.

The cell counting of beverages obtained with 24 $\mathrm{h}$ of fermentation is presented in Table 1 for each formulation, the results showed a steady growth of $\mathrm{LAB}$ (reaching over $10^{8} \mathrm{CFU} / \mathrm{mL}$ ) in all formulations (considering the inoculum of $1.0 \cdot 10^{6}$ $\mathrm{CFU} / \mathrm{mL}$ ). According to the Brazilian legislation, the minimum value for $\mathrm{LAB}$ cell counting in lactic fermented beverages is established as $10^{6} \mathrm{CFU} / \mathrm{mL}$ (Brazil, 2001), therefore, all formulations are in agreement to this specification and can be classified as lactic fermented beverages. It is worth noting that there was an expressive growth of LAB with formulations (trials) 4, 6, 8 and 9 whose proportions varied from: 40 to $60 \%(\mathrm{v} / \mathrm{v})$ for mango, $35-50 \%$ $(\mathrm{v} / \mathrm{v})$ for whey and $0-15 \%(\mathrm{v} / \mathrm{v})$ of milk (Tab. 1). The influence of mango in LAB growth was also verified in a previous study that evaluated lactic fermented beverage with whey, in which the addition of mango in the formulations increased the cellular counting of $L$. casei cells in $1 \log$ UFC after $24 \mathrm{~h}$ compared with formulations without mango (Desnilasari and Kumalasari, 2017). Other similar counting for mango based lactic fermented beverages has been reported such as $10^{7}-10^{8}$ CFU/mL (Maldonado et al., 2017) and $9.81 \mathrm{log}$ UFC $/ \mathrm{mL}$ (Liao et al., 2016). 


\section{Initial sensory analysis}

Since fermentation was considered stable for the first $24 \mathrm{~h}$, as discussed before, the ten beverages obtained with $24 \mathrm{~h}$ were submitted to sensory evaluation, firstly, with a reduced group of 15 untrained assessors; the average scores obtained (Tab. 1) were statistically analysed. Three of the six attributes evaluated were adjusted to statistically significant models: $\left(R^{2}=0.61\right.$ and $\left.p=0.04\right)$, color $\left(R^{2}=0.76\right.$ and $\left.p=0.01\right)$, and global acceptance $\left(R^{2}\right.$ $=0.76 p=0.01)$ and their contour curves are presented in Figure 3. From the analysis of the contour curves it was observed the increase in mango proportion resulted in an increase in the assessors' marks to taste (Fig. 3.a), color (Fig. 3.b), and global acceptance (Fig. 3.c) and, an increase in milk proportion, resulted in an opposite (and undesirable) effect. This is a significant result as it demonstrates mango's potential as a substrate for the production of a lactic fermented beverage with high sensory acceptance and low lactose content.
Aroma was the attribute that presented the lowest acceptance, varying between 2.9 and 3.8 (58 to $76 \%$ acceptability index) (Tab. 1). And considering the attributes sweeteness and acidity, the average scores were around 3 (the center of the scale): $2.8 \pm 0.3$ and $3.0 \pm 0.2$, respectively (Tab. 1), therefore, these attributes were considered adequate. This is also an indication that the addition of sucrose in order to improve the taste was also favourable and it has been confirmed in other studies with satisfactory sensory acceptance results (Maldonado et al., 2017; Nogueira et al., 2016).

According to Table 1, formulations 1 and 4 presented the best results, especially for global acceptance (score $>4.0$, representing more than 80 $\%$ of the acceptability index), and these two formulations are precisely the ones that do not contain milk. Additionally, since the increase in mango proportion improved the sensory acceptance, a formulation with only mango pulp was chosen with formulations 1 and 4 for the final validation and sensory analysis. a) Taste

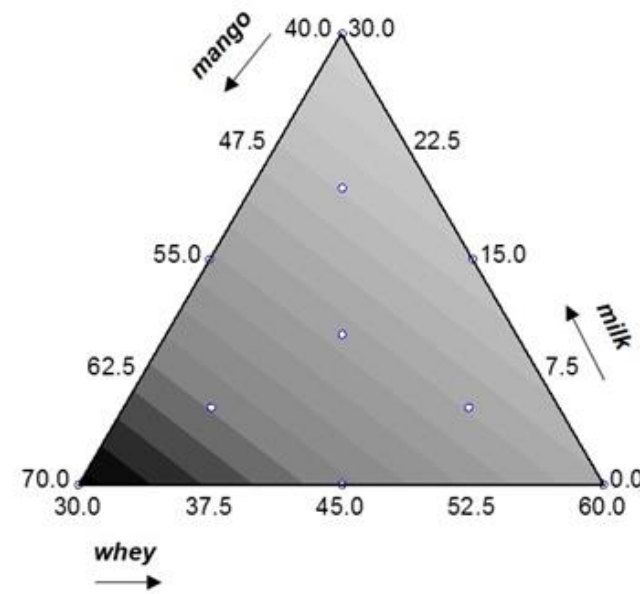

b) Color

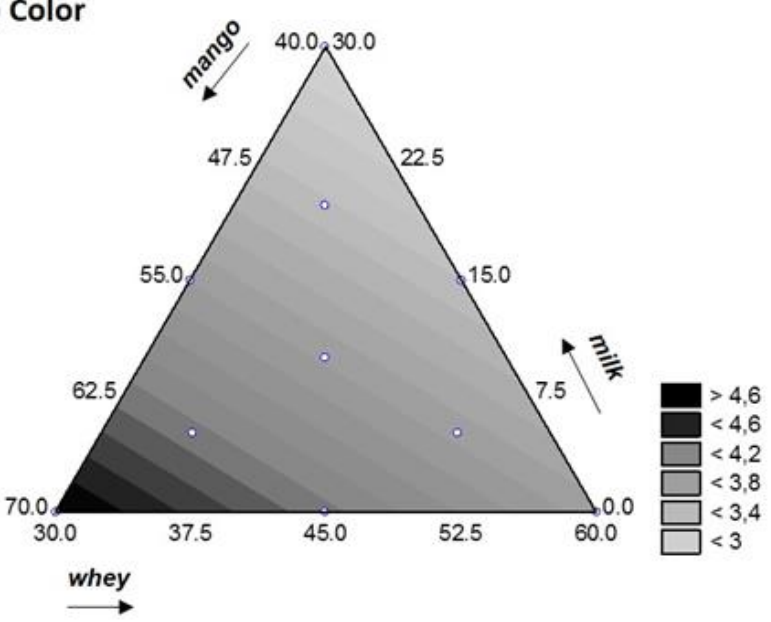

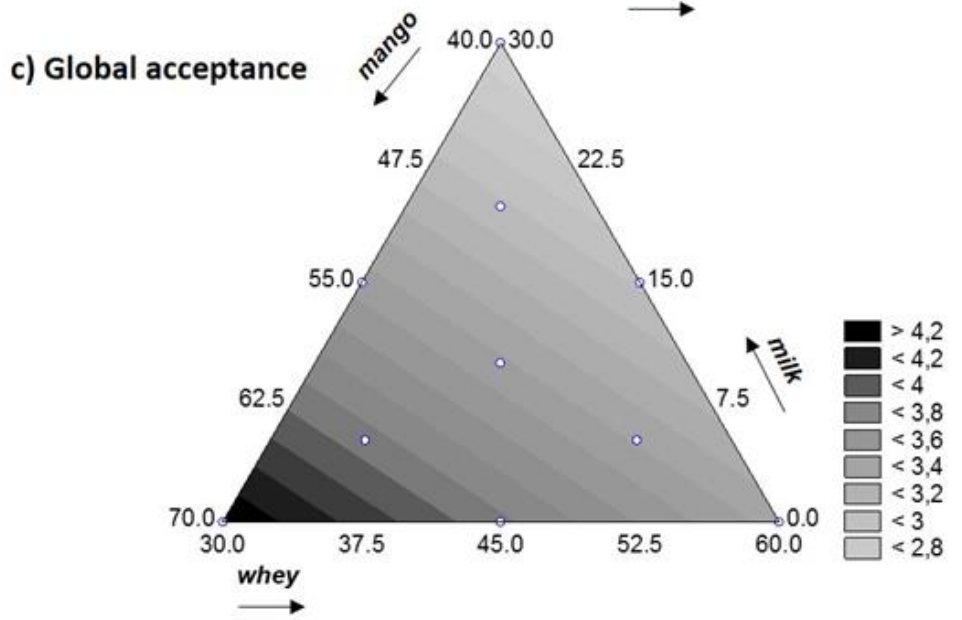

Figure 3 - Contour curves for the sensory analysis of lactic fermented $(24 \mathrm{~h})$ beverages developed with different proportions $(\%, w / w)$ of mango pulp, whey and whole milk for the attributes: a) taste, b) color and c) global acceptance 


\section{Validation}

The results for $\mathrm{pH}$ and SS for the three selected formulations are shown in Table 2. The analysis shows that initially $(t=0 \mathrm{~h})$, the lowest $\mathrm{pH}$ was obtained with only mango pulpas a substrate but at $t=24 \mathrm{~h}$, the lowest proportion of mango resulted in the lowest $\mathrm{pH}$. Regarding the SS values, the formulation with $70 \%(\mathrm{w} / \mathrm{w})$ of mango was statistically different from the other two formulations, this tendency remained unaltered with the fermentation as observed before with the mixture design. The coefficients of variation $(\mathrm{CV})$ obtained were lower than $10 \%$ (Table 2) which indicate that there was a good reproducibility among the five replicates realized.

\section{Sensory analysis of the final formulations}

The results of the sensory analysis for the three selected formulations are presented in Table 3 . The results demonstrated no statistical significant difference $(p>0.05)$ between the three formulations for none of the attributes evaluated. Furthermore, a high global acceptance (from 82 to $88 \%$ ) for the three formulations was verified, this result confirms that, among all the formulations evaluated, the three formulations selected were those with the consumer's highest acceptance potential. This is a promising result since it was possible to elaborate the lactic fermented beverage utilizing mango and whey, without lactose, with a good sensory acceptance. The sensorial analysis also permitted to observe that whey has also the benefit to be incorporated in formulations without altering significantly the sensory acceptance.

Table 2 - Average values of $\mathrm{pH}$ and soluble solids (SS, ${ }^{\circ} \mathrm{Brix}$ ) at 0 and $24 \mathrm{~h}$ of lactic fermentation of mango pulp and whey formulations ( $\mathrm{n}=5$ replicates)

\begin{tabular}{|c|c|c|c|c|}
\hline \multirow{2}{*}{$\begin{array}{c}\text { Formulations } \\
\text { mango:whey } \\
\%(w / w)\end{array}$} & \multicolumn{2}{|c|}{$\mathbf{p H}$} & \multicolumn{2}{|c|}{ SS $\left({ }^{\circ}\right.$ Brix $)$} \\
\hline & O h & $24 \mathrm{~h}$ & $\mathbf{0 h}$ & $24 \mathrm{~h}$ \\
\hline HSD $(\alpha=0.05)$ & 0.33 & 0.13 & 0.96 & 0.74 \\
\hline 70:30 & $\begin{array}{c}5.13 \pm 0.06^{\mathrm{a}} \\
(\mathrm{CV}=1.20 \%)\end{array}$ & $\begin{array}{c}3.98 \pm 0.03^{\mathrm{a}} \\
(\mathrm{CV}=0.84 \%)\end{array}$ & $\begin{array}{c}4.80 \pm 0.45^{\mathrm{a}} \\
(\mathrm{CV}=9.32 \%)\end{array}$ & $\begin{array}{c}5.00 \pm 0.35^{\mathrm{a}} \\
(\mathrm{CV}=9.32 \%)\end{array}$ \\
\hline $55: 45$ & $\begin{array}{c}5.00 \pm 0.25^{\mathrm{b}} \\
(\mathrm{CV}=4.93 \%)\end{array}$ & $\begin{array}{c}3.89 \pm 0.03^{\mathrm{a}} \\
(\mathrm{CV}=0.88 \%)\end{array}$ & $\begin{array}{c}5.94 \pm 0.62^{\mathrm{b}} \\
(\mathrm{CV}=10.49 \%)\end{array}$ & $\begin{array}{c}5.98 \pm 0.25^{b} \\
(\mathrm{CV}=0.75 \%)\end{array}$ \\
\hline 100:0 & $\begin{array}{c}4.47 \pm 0.13^{\mathrm{c}} \\
(\mathrm{CV}=2.86 \%)\end{array}$ & $\begin{array}{c}4.27 \pm 0.09^{\mathrm{b}} \\
(\mathrm{CV}=2.19 \%)\end{array}$ & $\begin{array}{c}6.40 \pm 0.55^{\mathrm{b}} \\
(\mathrm{CV}=8.56 \%)\end{array}$ & $\begin{array}{c}6.50 \pm 0.50^{\mathrm{b}} \\
(\mathrm{CV}=7.69 \%)\end{array}$ \\
\hline
\end{tabular}

HSD = Honestly significant difference. $\mathrm{CV}=$ Coefficient of variation. Values in the same column, marked with different superscript letters are statistically different $(p<0.05)$

Table 3 - Average scores for the sensory evaluation of some attributes ( $n=58$ assessors) of lactic fermented beverages produced with different proportions $(\% \mathrm{w} / \mathrm{w})$ of mango pulp and whey

\begin{tabular}{|c|c|c|c|c|c|c|}
\hline $\begin{array}{c}\text { Formulations } \\
\text { mango:whey } \\
\text { \% (w/w) }\end{array}$ & Taste & Aroma & Color & $\begin{array}{c}\text { Overall } \\
\text { acceptance }\end{array}$ & Sweetness & Acidity \\
\cline { 2 - 7 } & $4.3 \pm 0.6$ & $4.2 \pm 0.8$ & $4.6 \pm 0.5$ & $4.3 \pm 0.6$ & $3.5 \pm 0.7$ & $3.0 \pm 0.7$ \\
\hline $\mathbf{7 0 : 3 0}$ & $4.4 \pm 0.8$ & $4.2 \pm 0.9$ & $4.7 \pm 0.6$ & $4.4 \pm 0.6$ & $3.2 \pm 0.7$ & $3.3 \pm 0.7$ \\
\hline $\mathbf{5 5 : 4 5}$ & $4.2 \pm 0.8$ & $4.0 \pm 0.8$ & $4.5 \pm 0.7$ & $4.1 \pm 0.8$ & $3.1 \pm 0.8$ & $3.2 \pm 0.9$ \\
\hline $\mathbf{1 0 0 : 0}$ & &
\end{tabular}

As regards the literature, studies on lactic fermented beverages fruit-based are not rare. However, there are still few studies in which fruit pulps are utilized in combination to whey or milk for the fermentation and not just added after fermentation for flavouring. Castro et al. (2013) evaluated the substitution of milk for whey in a strawberry flavored lactic fermented beverage and obtained the highest global acceptance $(77.8 \%)$, utilizing $35 \%(\mathrm{w} / \mathrm{w}$ ) of whey. Santos et al. (2008) evaluated the substitution of milk for whey in a lactic fermented beverage of mango (12\% w/w) and obtained a global acceptance of $86.6 \%$ utilizing $40 \%$ of whey. Desnilasari and Kumalasari (2017) also verified an increase in color and texture of a whey and mango pulp lactic fermented beverage, however, the addition of mango did not increase the global acceptance of the beverages. Maldonado et al. (2017) obtained lower sensory acceptance of $68.8 \%$ for taste, $74.4 \%$ for aroma and $91.1 \%$ for color also fermenting mango pulp, however, without the sugar addition before the sensory analysis.

The comparison with the literature indicates that the results obtained with the lactic fermented beverages of mango and mango with whey, in this 
study, are superior to those related previously. Therefore, under the conditions evaluated in this study, the selected formulations are promising for producing a commercial fruit-based lactic fermented beverage.

\section{CONCLUSIONS}

Fermented beverages (and other food products) with lower milk content or milk-free are nowadays a constant requirement from consumers, for different reasons. Fruit pulps are a potential candidates to replace milk in fermented lactic beverages and whey represents a low cost ingredient which can contribute to enrich formulations. The investigation for new substrates and fermentation conditions are important and must be stimulated in order to value local fruits, for example. From this present work, the investigation of the best compositions between mango pulp, whey and milk permitted to suggest three formulations - all milk free - as a substrate for $L$. acidophilus La-5 fermentation and to obtain fermented beverages with a good sensory acceptance. The use of fruit pulps, such as mango pulp (with or without whey) can result in different fermentation profiles than those obtained when milk is (traditionally) used. However, by using fruits and whey it is possible to develop new products with unique characteristics.

\section{ACKNOWLEDGMENTS}

The authors are grateful for the financial support from the Coordenação de Aperfeiçoamento de Pessoal de Nível Superior (CAPES, Brazil) and the Conselho Nacional de Desenvolvimento Científico e Tecnológico (CNPq, Brazil).

\section{REFERENCES}

Abdel-Hamid M, Romeih E, Gamba RR, Nagai E, Suzuki T, Koyanagi, $\mathrm{T}$ et al. The biological activity of fermented milk produced by Lactobacillus casei ATCC 393 during cold storage. International Dairy Journal, v.9, p.1-8, 2019. https://doi.org/10.1016/j.idairyj.2018.12.007

Andrade MR, Martins TR, Rosenthal A, Hauck JT, Deliza R. Fermented milk beverage: formulation and process. Ciência Rural, v.49, n.3, 2019. https://doi.org/10.1590/0103$8478 \mathrm{cr} 20180382$

Barana AC, Lima RC, Botelho VB, Simões DR. Development of a fermented dairy beverage using chesse quark sour whey. Revista Verde de Agroecologia e Desenvolvimento Sustentável, v.7, n.5, p.13-21, 2012.

Barros Neto B, Scarminio IS, Bruns RE. Como fazer experimentos: aplicações na ciência e na indústria. Bookman, Porto Alegre, RS. p.187-215.

Bourscheid C, Bedin AC, Schoder MA, Hornung PS, Barana AC, Demiate IM et al. Mix ready to prepare soup with fiber of common bean (Phaseolus vulgaris L.). Pesquisa
Agropecuária Brasileira, v.8, n.2, p.1618-1626, 2014. https://doi.org/10.3895/S1981-36862014000200014S1

Brazil. Ministry of Health. Resolution $\mathrm{n}^{\circ} 12$ from January $12^{\text {th }}$ of 2001. Diário Oficial da União, Brasília, DF.

Castro WF, Cruz AG, Bisinotto MS, Guerreiro LMR, Faria JAF, Bolini, HMA et al. Development of probiotic dairy beverages: Rheological properties and application of mathematical models in sensory evaluation. Journal of Dairy Science, v.96, p.16-25, 2013.

https://doi.org/10.3168/jds.2012-5590

Chen Z, Liu T, Ye T, Yang X, Xue Y, Shen y. Effect of lactic acid bacteria and yeasts on the structure and fermentation properties of Tibetan kefir grains. International Dairy Journal, v.114, 104943, 2021. https://doi.org/10.1016/j.idairyj.2020.104943

Daba GM, Elkhateeb WA. Bacteriocins of lactic acid bacteria as biotechnological tools in food and pharmaceuticals: Current applications and future prospects. Biocatalysis and Agricultural Biotechnology, v.28, 101750, 2020. https://doi.org/10.1016/j.bcab.2020.101750

Desnilasari D, Kumalasari R. Characteristic of fermented drink from whey cheese with addition of mango (Mangifera odorata) juice. IOP Conference Series: Earth and Enviromental Science, v.101, 012024, 2017. https://doi.org/10.1088/1755-1315/101/1/012024

Di Cagno R, Filannino P, Gobbetti M. Lactic acid fermentation drives the optimal volatile flavor-aroma profile or pomegranate juice, International Journal of Food Microbiology, v.248, p.56-62, 2017.

https://doi.org/10.1016/j.ijfoodmicro.2017.02.014

Di Cagno R, Codda R, De Angelis M, Gobbetti, M. Exploitation of vegetables and fruits through lactic acid fermentation. Food Microbiology, v.33, p.1-10, 2013. https://doi.org/10.1016/j.fm.2012.09.003

Di Cagno R, Minervini G, Rizzello CG, De Angelis M, Gobbetti M. Effect of lactic acid fermentation on antioxidant, texture, color and sensory properties of red and green smoothies. Food Microbiology, v.28, p.1062-1071, 2011. https://doi.org/10.1016/j.fm.2011.02.011

Filannino P, Azzi L, Cavoski I, Vincentini O, Rizzello, CG, Gobbetti $\mathrm{M}$ et al. Exploitation of the health-promoting and sensory properties of organic pomegranate (Punica granatum L.) juice through lactic acid fermentation. International Journal of Food Microbiology, v.163, p.184-192, 2013. https://doi.org/10.1016/j.ijfoodmicro.2013.03.002

Fonteles TV, Costa MGM, de Jesus ALT, Fontes CPML, Fernandes FAN, Rodrigues S. Stability and quality paramenters of probiotic cantloupe melon juice produced with sonicated juice. Food Bioprocess Technology, v.6, p.28602869, 2013. https://doi.org/10.1007/s11947-012-0962-y

Fujita A, Sarkar D, Genovese MI, Shetty K. Improving antihyperglycemic and anti-hypertensive properties of camucamu (Myriciaria dubia Mc. Vaugh) using lactic acid bacterial fermentation. Process Biochemistry, v.59, p.133-140, 2017. https://doi.org/10.1016/j.procbio.2017.05.017

Garcia C, Guerin M, Souidi K, Remize F. Lactic Fermented Fruit or Vegetable Juices: Past, Present and Future. Beverages, v.8, n.6, 2020. https://doi.org/10.3390/beverages6010008 
Garcia SLA, Silva GM, Medeiros JMS, Queiroga APR, Queiroz BB, Farias DRB et al. Influence of co-cultures of Streptococcus thermophilus and probiotic lactobacilli on quality and antioxidant capacity parameters of lactosefree fermented dairy beverages containing Syzygium cumini (L.) Skeels Pulp. The Royal Society of Chemistry, v.10, p.10297-10308, 2020. https://doi.org/10.1039/c9ra08311a

Gobbetti M, Di Cagno R, Calasso M, Neviani R, Fox PF, de Angelis M. Drivers that establish and assembly the lactic acid bacteria biota in cheeses. Trends in Food Science \& Technology, v. 78, p. 244-254, 2018. https://doi.org/10.1016/j.tifs.2018.06.010

Guimarães JT. et al. Effect of high-intensity ultrasound on the nutritional profile and volatile compounds of a prebiotic soursop whey beverage. Ultrasonics Sonochemistry, v.55, p.157-164, 2019.

https://doi.org/10.1016/j.ultsonch.2019.02.025

Huang Y, Yu J, Zhou Q, Sun L, Liu D, Liang, M. Preparation of yogurt-flavored bases by mixed lactic acid bacteria with the addition of lipase. LWT - Food Science and Technology, v.131, 109577, 2020.

https://doi.org/10.1016/j.lwt.2020.109577

IAL. Métodos Analíticos do Instituto Adolfo Lutzs. Imesp, São Paulo, SP. p.340-350. 2005.

Isas AS, Celis MSM, Correa JRP, Fuentes E, Rodríguez L, Palomo I et al. Functional fermented cherimoya (Annona cherimola Mill.) juice using autochthonous lactic acid bacteria. Food Research International, v.138, 109729, 2020. https://doi.org/10.1016/j.foodres.2020.109729

Liao XY, Guo LQ, Ye ZW, Qiu LY, Gu, FW, Lin JF. Use of autochthonous lactic acid bacteria starters to ferment mango juice for promoting its probiotic roles. Preparative Biochemistry and Biotechnology, v.46, n.4 p.399-405, 2016. https://doi.org/10.1080/10826068.2015.1045615

Maldonado RR, Araújo LC, Dariva LCS, Rebac KN, Pinto IAS, Prado, JPR et al. Potential application of four types of tropical fruits in lactic fermentation. LWT- Food Science and Technology, v.86, p.254-260, 2017. https://doi.org/10.1016/j.lwt.2017.08.005

Moussa MEM, El-Gendy MA. Physiochemical, microbiological and sensory properties of guava whey blend beverages. Middle East Journal of Applied Sciences, v.9, p.326-331, 2019.

Nagpal R, Kumar A, Kumar M. Fortification and fermentation of fruit juices with probiotic lactobacilli. Annals of Microbiology, v.62, p.1573-1578, 2012. https://doi.org/10.1007/s13213-011-0412-5

Nogueira LK, Aguiar-Oliveira E, Kamimura ES, Maldonado RR. Milk açaí berry pulp improve acceptability of kefirfermented milk beverage. Acta Amazonica, v.46, p.417424, 2016. https://doi.org/10.1590/1809-4392201600173

Pandey A, Mishra AA, Shukla RN, Dubey PK, Vasant RK. Development of the Process for Whey Based Pineapple Beverage. Excellent Publishers, v. 8, n. 6, p. 3212-3228, 2019. https://doi.org/10.20546/ijcmas.2019.806.383

Pandey S, Ojha P. Preparation and Quality Evaluation of Mango based Whey Beverage. Journal of Food Science and Technology Nepal, v.12, n.12, p.59 -61, 2020. https://doi.org/0.3126/jfstn.v12i12.33375
Peirotén A, Gaya P, Landete JM. Application of recombinant lactic acid bacteria and bifidobacteria able to enrich soy beverage in dihydrodaidzein and dihydrogenistein. Food Research International, v.134, 109257, 2020. https://doi.org/10.1016/j.foodres.2020.109257

Peng K, Koubaa M, Bals O, Vorobiev E. Recent insights in the impact of emerging technologies on lactic acid bacteria: A review. Food Research International, v.137, 109544, 2020. https://doi.org/10.1016/j.foodres.2020.109544

Pereira ALF, Feitosa WSC, Abreu VKG, de Oliveira Lemos $\mathrm{T}$, Gomes WF, Narain N et al. Impact of fermentation conditions on the quality and sensory properties of a probiotic cupuassu (Theobroma grandiflorum) beverage. Food Research International, v. 100, p. 603-611, 2017. https://doi.org/10.1016/j.foodres.2017.07.055

Rama GR, Kuhn D, Beux S, Maciel MJ, Souza, CFV. Potential applications of dairy whey for the production of lactic acid bacteria cultures. International Dairy Journal, v.98, p.25-37, 2019. https://doi.org/10.1016/j.idairyj.2019.06.012

Reddy LV, Min JH, Wee YJ. Production of probiotic mango juice by fermentation of lactic acid bacteria. Microbial Biotechnology Letters, v.43, p.120-125, 2015. https://doi.org/10.4014/mbl.1504.04007

Santos CT, Costa AR, Fontan GCR, Fontan RDCI, Bonomo $\mathrm{RCF}$. The influence of whey concentration in the sensorial acceptance of fermented lactic beverage with mango pulp. Alimentos e Nutrição Araraquara, v.19, p.55-60, 2008. https://doi.org/10.3168/jds.2012-5590

Skyplonek K, Dmytrów I, Malek AM. Probiotic fermented beverages based on acid whey. Journal of Dairy Science, v.102, n.9, p.7773-7780, 2019. https://doi.org/10.3168/jds.2019-16385

Souza HF, Borges LA, Lopes JPA, Carvalho BMA, Santos SHS, Almeida AC et al. Elaboration, evaluation of nutritional information and physical-chemical stability of dairy fermented drink with caja-mango Pulp. Ciência Rural, v.50, n.1, e20190644, 2020. https://doi.org/10.1590/0103$8478 \mathrm{cr} 20190644$

Souza FRM, Santos NGS, Padilha DMM, Bezerra DS, Felipe MBMC, Ramalho HMM. Probiotic fermented milk drink added with cashew pulp (Anacardium occidentale): formulation, physicochemical, microbiological and sensory characteristics. Research, Society and Development, v.9, n.8, e990986753, 2020. https://doi.org/10.33448/rsd-v9i8.6753

Wu J, Zhang Y, Ye L, Wang C. The anti-cancer effects and mechanisms of lactic acid bacteria exopolysaccharides in vitro: A review. Carbohydrate Polymers, v.253, 117308, 2021. https://doi.org/10.1016/j.carbpol.2020.117308

Yerlikaya O, Saygili D. Akpinar A. Evaluation of antimicrobial activity and antibiotic susceptibility profiles of Lactobacillus delbrueckii subsp. bulgaricus and Streptococcus thermophilus strains isolated from commercial yoghurt starter cultures. Food Science and Technology, v.41, n.2, p.418-425, 2021. https://doi.org/10.1590/fst.03920 